\title{
DEBATING “GREATNESS” FROM MACHIAVELLI TO BURTON*
}

\author{
Sara Miglietti (University of Warwick)
}

\begin{abstract}
From early humanist treatises on city government in Italy to Rousseau's Social Contract, "greatness" (grandezza, grandeza, grandeur) was often presented as both the aim that political communities should pursue and the touchstone to measure their relative success. But what exactly should be understood by "greatness", and how could it be achieved? Although most authors agreed that it took more than a large territory for a state to be truly "great", they all seemed to prioritise different things: political liberty, military strength, material wealth, absence of strife, a solid social and political order, or the happiness and overall wellbeing of the citizens. In an age of state- and empire-building, the debate on the nature of political "greatness" raised critical questions and contributed to shaping the agenda and the selfrepresentation of European powers. By concentrating on a few selected thinkers (Machiavelli, Bodin, Botero, Bacon, Burton) whose works form a complex network of mutual influences, this chapter seeks to investigate an exemplary case of unceasing dialogue between the Renaissance and the early modern period.
\end{abstract}

\section{Machiavelli, Italian Humanism, and the Ideology of Greatness}

Truly it is a marvelous thing to consider to what greatness (grandezza) Athens came in the space of a hundred years after she freed herself from the tyranny of Pisistratus. But above all, it is very marvelous to observe what greatness (grandezza) Rome came to after she freed herself from her kings. ${ }^{1}$

Notwithstanding his well-justified "marvel" at the progress made by Athens and Rome under a "free government" (vivere libero), the Florentine writer Niccolò Machiavelli (1469-1527) was probably aware that his words would be of little surprise to the readers of his Discourses on Livy (composed around 1513-1517 but first published in 1531). Many of these, indeed, would have easily recognised that the Florentine was subscribing to a discourse whose roots could be traced back to Roman moralists and historians such as Sallust, and which had been revived in Italy since at least two centuries. ${ }^{2}$ The very word grandezza had made its first appearance in thirteenth-century vernacular writers such as Matteo de' Libri, Giovanni da Vignano, Guido Faba and Filippo Ceffi, who coined this term to signify the highest end to which political communities could aspire. ${ }^{3}$ Although the concept was typically Roman, ${ }^{4}$ the

\footnotetext{
* I would like to thank David Lines for comments on an earlier draft of this chapter.

${ }^{1}$ Machiavelli (1965), II.2, 329; Machiavelli (1999), II.2, 297.

${ }^{2}$ Hörnqvist (2004), 74.

${ }^{3}$ Skinner, quot. in Springborg (1992), 198-199; Skinner (2003), 92-93.

${ }^{4}$ Springborg (1992), 197-198.
} 
word itself was not. As noted by Skinner, classical Latin lacked an expression "at once denoting grandeur and magnitude", 5 and those "pre-humanist" Italian authors who wrote in Latin usually turned to vaguer synonyms (such as "incrementum") ${ }^{6}$ or created curious pastiches by weaving the Italian word grandezza into Latin texts. ${ }^{7}$ For these authors, grandezza was an essential component of a healthy civic life (bon stato), ${ }^{8}$ alongside domestic peace (riposo), dignity (honore) and, crucially, political freedom. ${ }^{9}$ Towards the beginning of the fifteenth century, this notion of self-government as the only way to achieve bon stato and grandezza, ${ }^{10}$ originally inspired by classical authors such as Aristotle, Cicero and Sallust, was bound to become the keystone of Florentine self-representations, ${ }^{11}$ and was frequently used to sustain and justify the aggressive "republican imperialism" of the Tuscan city-state. ${ }^{12}$

Machiavelli's Discourses, written more than a hundred years later and under profoundly changed historical circumstances, have been rightly identified as the ultimate and possibly highest expression of this tradition coupling liberty and empire in the pursuit of political grandezza. ${ }^{13}$ For the late medieval and early humanist authors who wrote before Machiavelli, grandezza had at once a spatial, a material, and an ethical-political meaning, denoting not only the magnitude of a state's territory, but also its wealth, standing, power, and most importantly its vivere civile (a well-ordered, republican way of life). ${ }^{14}$ The same holds true for Machiavelli, who describes grandezza in terms of both territorial extension (dominio and corpo $)^{15}$ and wealth (ricchezza), ${ }^{16}$ equates it with military power, ${ }^{17}$ and establishes a direct link between self-government (vivere libero) and greatness thus conceived. The polysemy of Machiavellian grandezza did not escape early translators such as Johann Nikolaus Stupanus, whose Latin version of Discourses (1588) formed the basis for most subsequent Latin

\footnotetext{
${ }^{5}$ Skinner (2003), 92.

${ }^{6}$ Skinner (2003), 92.

${ }^{7}$ See for instance Giovanni da Viterbo's Liber de regimine civitatum, quot. in Skinner (2003), 93.

${ }^{8}$ Skinner (1995), 108.

${ }^{9}$ Skinner (2003), 92-93; Hörnqvist (2004), 39-40.

${ }^{10}$ Skinner (1995), 104.

11 The most famous example is Leonardo Bruni's Laudatio Florentinae Urbis, written around 1403-1404, but see Hörnqvist (2004), 55-70, for further examples.

12 Hörnqvist (2004), 42, building on previous work by Hankins (1995 and 2000), Najemy (2000) and Brown (2004).

${ }^{13}$ Springborg (1992), 197; Skinner (2003), 103-106; Hörnqvist (2004), 72-74.

${ }^{14}$ Skinner (2003), 91, correcting Springborg's somewhat unilateral view of grandezza as something "literally spatial" $(1992,198)$.

${ }^{15}$ Machiavelli (1999), II.2, 297, 301; Machiavelli (1965), II.2, 329, 333.

${ }^{16}$ Machiavelli (1999), II.2, 297, 300; Machiavelli (1965), II.2, 329, 332.

${ }^{17}$ See for instance Machiavelli (1965), II.2, 332: "The Roman Empire with her arms (arme) and her greatness (grandezza) wiped out all the republics and all the self-governing communities (e viveri civili)"; Machiavelli (1999), II.2, 299-300.
} 
editions of the work: ${ }^{18}$ in the absence of an exact Latin equivalent for the Italian word grandezza, Stupanus chose to translate the latter in more than one way, thus brilliantly capturing its multiple meanings. ${ }^{19}$

While interpreting grandezza in accordance with a well-established tradition, Machiavelli moved a step forward in identifying the factors that could affect its achievement. Although a constitutional form ensuring political liberty was just as decisive for him as it had been for his forebears, the Florentine saw that other aspects needed to be taken into account as well. First and foremost among these was a consideration of the size and features of the local population. According to Stangeland, Machiavelli was "perhaps the first to express ideas of modern tone on population"; ${ }^{20}$ at the very least, he was among the earliest authors to acknowledge the centrality of demographic issues for political theory, and advocated population growth in a time when the dominant ideal was still that of a fixed and relatively small population size. Machiavelli's main point in favour of population growth was that no great empire can be established without a sizeable population, given the high demographic costs of expansionism. ${ }^{21}$ Not by chance, he argued, the Romans sought to increase their population by all possible means, and particularly through their citizenship policies. ${ }^{22}$

In sum, just as the achievement of grandezza requires territorial expansion, the latter demands population growth. Machiavelli did not regard expansionism and demographic increase as good in themselves, but only as means to a higher end - namely greatness. He was also acutely aware of their problematic nature: while territorial expansion was among the causes that ultimately led the Roman Empire to collapse, ${ }^{23}$ a large population can turn from a strength into a handicap if the country is not sufficiently wide, or sufficiently rich, to sustain it. ${ }^{24}$ Territory and population are thus subtly related by Machiavelli so as to emphasise their crucial, and often delicate, balance. It is not simply a matter of size: the qualitative features of the terrain influence the people who live on it, ${ }^{25}$ just as the latter constantly alter and reshape

\footnotetext{
18 See Ruffo Fiore (1990), 40.

19 Machiavelli (1588), 270-271, 276: “Admiratione summa dignum est Athenienses Pisistrati tyrannide liberatos, centum annorum spacio, vires atque potentiam suam tantopere augere potuisse. Et longe magis stupendum adhuc, Romanorum Rempublicam, expulsis Regibus, ad tantum fastigium pervenire potuisse [...] equidem Romani imperii magnitudo, non parum etiam ad id fecit, cum per universum orbem liberas Respublicas sub suum iugum subiecerit" (my emphasis).

${ }^{20}$ Stangeland (1904), 92.

${ }^{21}$ Machiavelli (1999), I.6, 77; II.3, 301-302.

${ }^{22}$ Machiavelli (1999), II.3, 302-303.

${ }^{23}$ In keeping with Sallust's account in Bellum Catilinae (X.1-2), which became the standard view of Roman decadence in the Renaissance: see Armitage (2002).

${ }^{24}$ Cf. Stangeland (1904), 93.

${ }^{25}$ Machiavelli (1965), I.1, 193-194; Machiavelli (1999), I.1, 62-63. See Glacken (1976), 433-434.
} 
the former through industry, architecture and agriculture. ${ }^{26} \mathrm{We}$ shall see in the next sections how Machiavelli's perceptive insights into the relationship between territory and population inspired and stimulated later authors grappling with the question of political greatness.

\section{2. "The Greatness of Cities": Botero and Bodin}

The year 1588 constituted a milestone in the discussion on grandezza. It was in this year that Giovanni Botero (1544-1617) published in Rome his Causes of the Greatness and Magnificence of Cities (Cause della grandezza e magnificenza delle città). The work, comprised of three books and written in Botero's elegant Italian, was an immediate success. It was reprinted the following year as an appendix to Botero's even more influential Reason of State (Ragion di Stato); and while the two treatises were frequently published together, the Greatness of Cities also enjoyed a separate fortune, with new editions and translations all over Europe until the mid-seventeenth century. ${ }^{27}$ The tract was especially successful in England, where it was printed twice in two distinct English translations (by Robert Peterson in 1606, and by Thomas Hawkins in 1635) and, as we shall see in section 3, received the close attention of many leading authors of the time.

Botero's treatise was seminal in many respects. As noted by Symcox, it departed from a century-long tradition of urban literature - from Leon Battista Alberti to Filarete and Francesco di Giorgio Martini - by shifting "the focus of enquiry from the forma urbis and the geometry of fortifications to economics, demography, and the political factors that foster urban development, causing some cities to prosper while others do not". ${ }^{28}$ Among such causes of urban development, Botero identified three main topographical factors ("the commodity of the site, the fertility of the soil and easiness of conduct", according to Peterson's translation), ${ }^{29}$ and a number of economic, social and political aspects that he carefully reviewed in book 2 . Some of these were clearly inspired by a reading of republican Rome through the lens of Machiavelli's Discourses, as is especially evident in the sections on citizenship and colonies. ${ }^{30}$ Recent studies have shown how the influence of Machiavelli was crucial for the development of Botero's thought; ${ }^{31}$ yet at the same time it must be noted that Botero was critical of Machiavelli for reasons that go well beyond the Florentine's alleged

\footnotetext{
${ }^{26}$ See Stangeland (1904), 93.

${ }^{27}$ See Botero (2012), xiii-xiv.

${ }^{28}$ Botero (2012), vi.

${ }^{29}$ Botero (1956a), I.7, 234 and (1990a), I, 318.

${ }^{30}$ Botero (1956a), II.1-2, 244-247 and (1990a), II, 330-334.

${ }^{31}$ See in particular Descendre (2009).
} 
atheism and amorality, and which involve their divergent understandings of what political greatness is and how it can (or should) be achieved.

"The greatness of a city is said to be, not the largeness of the site or the circuit of the walls, but the multitude and number of the inhabitants and their power", wrote Botero in the opening lines of his treatise, ${ }^{32}$ thus revealing at once his dependence on, and departure from, the author of Discourses. Indeed, by saying that the "greatness" of a city should be measured by the number (moltitudine) and power (possanza) of its population rather than by its spatial extension, Botero was directly targeting Machiavelli's equation of territory and population, as well as his emphasis on territorial expansion. On the other hand, the two agreed that an expansionist programme necessarily requires the implementation of policies encouraging population growth. ${ }^{33}$ In his Universal Relations (Relationi Universali, a geographical and political description of several world countries) of 1596, Botero gave numerous examples of how engaging in wars of conquest can prove devastating for an under-populated country. $\mathrm{He}$ argued with remarkable foresight that Spain and Portugal were destined to a rapid decline, for so many young men were lost every year in the colonial effort that "the homeland remains almost lifeless and devoid of vigour". ${ }^{34}$ The two Iberian countries were following "a reason of state exactly opposed to that which made Rome great and powerful", having failed to augment their population in preparation for their expeditions and thus exhausting themselves in an undertaking which would bring them ruin rather than grandezza. ${ }^{35}$ As a counterexample Botero cited the case of the Chinese, who - he said - wisely abandoned their aggressive expansionism as soon as they realised that the war against India could only be won at the expense of immense human and material losses, and now happily prospered within fixed borders. $^{36}$

"What good is it to struggle to expand, when expansion not only does not bring about wellbeing (bene essere), but destroys being (essere)?" wonders Botero. ${ }^{37}$ For him, the primary goal of a good ruler should be to protect and preserve the state, not to increase it. He is aware, of course, that this viewpoint contradicts Machiavelli's famous argument that rulers do not

\footnotetext{
${ }^{32}$ Botero (1956a), I.1, 227 and (1990a), I, 309.

${ }^{33}$ See for instance Botero (1596), II, "Proemio" (unpaged); Botero (1956b), VII.12, 144-7 and (1990b), VII, 201-205.

${ }^{34}$ Botero (1596), I.1 ("Cina"), 17 (all translations from Universal Relations are mine). Cf. Botero (1956b), VII.12, 145 and (1990b), VII, 203-204. Botero was expressing concerns that would spread in Spain several years later, particularly in the late reign of Philip III: cf. Elliott (1977) and Spedding in Bacon (1900a), 127-129, footnote 2 .

${ }^{35}$ Further distinctions between ancient Roman policies and the short-sighted colonialism of the Spanish and the Portuguese are made in Botero (1956b), VIII.5, 156-157 and (1990b), VIII, 219-220.

${ }^{36}$ Botero (1596), I.1 ("Cina"), 125-126.

${ }^{37}$ Botero (1596), II.1 ("Moscovia"), 41.
} 
really have a choice between preservation and expansion, since states are generally forced to expand in order to survive. ${ }^{38}$ But Botero is unconvinced: in fact, middle-sized states have better chances of surviving than large empires, ${ }^{39}$ and by rechanneling their energies from wasteful military undertakings into the systematic exploitation and improvement of their own territory, they are also often wealthier, healthier, and more densely populated - which, for Botero, is itself a measure of "greatness". 40

Besides, military conquest is not the only way in which states can expand. Although war remains unquestionably an important component of Botero's mental universe, ${ }^{41}$ the former Jesuit tends to see trade as a more benign and cost-effective way of securing one's power. ${ }^{42}$ Among the many examples of relatively small countries that have thrived by choosing commerce over war, he mentions the Flanders: here, where a substantial amount of money and energy has been invested into the construction of artificial channels that would make the transportation of goods easier and faster, a significant boost "to merchandising and to the traffic of other nations" has ensued. ${ }^{43}$

Botero was among the first to grasp the economic principle according to which the wealth of a state depends essentially on its having a favourable balance of trade - a principle that would later be formulated by authors such as Thomas Mun. ${ }^{44}$ But clearly commerce is only a viable option where there is a surplus available for export. No wonder then that Botero would express his admiration for all those countries that not only exploit their territory to the fullest and do not let anything go to waste, ${ }^{45}$ but seek to produce more than they need for internal consumption and also engage in manufacturing (arteficii) ${ }^{46}-$ an activity that enables them to export transformed goods rather than less lucrative raw materials. ${ }^{47}$ Botero's hints at the added value of labour have been seen by some as an anticipation of later theories (particularly

\footnotetext{
${ }^{38}$ Machiavelli (1999), I.6, 78-79 and (1965), I.6, 210-211. Botero admits that his preference for preservation over expansion "would not be approved by modern wisdom (prudenza moderna)" (1596, II.1, 41).

${ }^{39}$ Botero (1956b), I.6, 7-9 and (1990b), I, 7-10.

${ }^{40}$ For examples of "improvement" (miglioramenti), see Botero (1956b), III.2, 76 and (1990b), III, 106; Botero (1956b), VIII.2-3, 148-153 and (1990b), VIII, 207-214. Slack (2014) briefly discusses the place of Botero within the early modern tradition of "improvement".

${ }^{41}$ Descendre (2009) has stressed the Machiavellian inspiration behind Botero's discourse on "force", "power", and military prowess (see particularly chapter 4, 140-142).

42 See Hartman and Weststeijn (2013), 14. According to Hörnqvist (2004), Machiavelli would not have seen trade as "a tenable alternative" to military conquest, since "in his zero-sum world, commerce is also a form of imperialism" (74, n. 110).

${ }^{43}$ Botero (1956a), I.10, 238 and (1990a), I, 323.

${ }^{44}$ Botero (1956b), VII.10, 142-143 and (1990b), VII, 199. Mun's England's Treasure by Foreign Trade was written around 1630 but only published in 1664 .

${ }^{45}$ China is again proposed as a positive example: see Botero (1596), I.2 (“Cina”), 125; Botero (1956a), II.11, 266-9 and (1990a), II, 359-60; Botero (1956a), II.11, 268 and (1990a), II, 359.

${ }^{46}$ See again Botero's praise of Flanders in Botero (1596), II.2 ("Cina”), 65.

${ }^{47}$ Botero (1956b), VIII.3, 151 and (1990b), VIII, 211.
} 
by William Petty and Richard Cantillon), ${ }^{48}$ while his pioneering insights into the strategic importance of manufacturing are likely to have inspired part two of Antoine de Montchrétien's Traicté d'oeconomie politique (1615), one of the key economic works of the seventeenth century. ${ }^{49}$

Botero thus added a crucial component to the multifaceted understanding of grandezza that had been framed by the Italian humanists and redefined by Machiavelli. A flourishing economy - based on a range of extractive, productive, and commercial activities ("Agricoltura, Arte e traffichi") ${ }^{50}$ - was for him just as important as, if not more important than, a strong army for securing political greatness. ${ }^{51}$ Both Machiavelli and Botero advocated population growth; but while the former did so mainly for military reasons, Botero, though certainly not insensitive to the strategic advantages of a large population, also appreciated the fact that a well-inhabited country is usually better tilled, more thoroughly exploited, and ultimately more productive than an under-populated one. ${ }^{52}$

Botero was also acutely aware that demographic expansion was only good to the extent that it remained manageable. Machiavelli had already stressed the importance of keeping a sustainable balance between the size of a state's territory and that of its population: besides restating his point, ${ }^{53}$ Botero adds that a large population demands a careful management of urban spaces so as to minimise conflict, and public policies that guarantee high standards of hygiene. ${ }^{54}$ Botero's interest in public health is not merely motivated by the obvious consideration that large concentrations of people are ideal cradles of epidemic diseases; the former Jesuit is also concerned with providing each citizen with a good quality of life, which includes a safe and clean environment and an adequate education. ${ }^{55}$ Overall, he argues, the greatness of a state is not merely a matter of quantity. Quality counts too, and a wise prince should seek to "increase his forces intensively" as well as "extensively" 56 - striving to improve the "character" of his subjects rather than just focusing on numbers.

Botero was not alone in his effort to rethink Machiavellian grandezza in the service of early modern governmental practices. The Flemish Justus Lipsius (1547-1606) - whose Politica

\footnotetext{
${ }^{48}$ See Descendre (2009), 192-194.

${ }^{49}$ See Reinert (2011), 5.

${ }^{50}$ Botero (1956b), VII.10, 143 and (1990b), VII, 199-200.

${ }^{51}$ See Weber (2003), 328.

${ }^{52}$ Botero (1956b), VII.12, 144-147 and (1990b), VII, 201-205. Spain is again presented as a negative example.

${ }^{53}$ See Botero (1956a), III.2, 276-277 and (1990a), III, 371-372. Cf. Botero (1956b), VIII.4, 155 and (1990b), VIII, 217.

${ }^{54}$ See Botero (1956a), V.7, 109-110 and (1990a), V, 152 (on public order); Botero (1956b), VIII.4, 155 and (1990b), VIII, 217 (on public health).

${ }^{55}$ Botero (1956b), VIII.4, 154 and (1990b), VIII, 215. Cf. Weber (2003), 330.

${ }^{56}$ Botero (1956b), IX.1, 168 (modified translation) and (1990b), IX, 234.
} 
came out in Leiden in the same year as Botero's Reason of State (1589) and was translated into English five years later - was also moving in the same direction, drawing attention to economy and taxation as fundamental aspects of statecraft and thus marking a significant step in the discussion on political greatness. ${ }^{57}$ Behind Botero's and Lipsius's reframing of grandezza lurks the influence of Jean Bodin (1529/30-1596), the French jurist and political writer who crucially revisited the concept of sovereignty in his Six Books of the Commonwealth (Six livres de la République) - first published in French in 1576, largely reworked for the Latin edition of 1586, and translated into English by Richard Knolles in 1606.

Surely, the word grandeur (French for "greatness") retains in Bodin the same polysemy that it originally had in the Italian tradition before Botero. Nothing indicates that the Frenchman ever tried to circumscribe its meaning and uses in the same way that Botero would a few years after him. When the term appears in his vernacular works, it is often to indicate very literally the size of something, as when the Frenchman speaks of the "grandeur" of buildings and human bodies. ${ }^{58}$ When used alone, grandeur usually signifies social standing ${ }^{59}$ dignity (particularly royal dignity), ${ }^{60}$ or actual power, ${ }^{61}$ although on a few occurrences it stands for liberality and magnificence, in an interesting recovering of the Hellenistic notion of megalopsychia - another distant relative of humanist grandezza according to Springborg. ${ }^{62}$ Finally, the word is also employed to denote sheer territorial extension, as when Bodin refers to the "grandeur" of the Turkish Empire. ${ }^{63}$ Bodin's understanding of greatness is in sum quite flexible and, overall, not particularly original. Besides, the Frenchman does not seem to view grandeur (as he conceives of it) as a primary objective of good statecraft: stable government, absence of strife, and the happiness and well-being of the citizens (their vivre heureusement) are indeed the parameters by which he thinks that a state's success should be measured, with all other considerations coming second.

Yet, even though Bodin does not specifically contribute to the discussion on "greatness" in any significant way, his work contains highly original insights into the conditions of political development that would prove a fundamental source of inspiration for Botero. On the one hand, he acted as a positive mediator of Machiavellian ideas, for instance by echoing the

\footnotetext{
${ }^{57}$ See Weber (2003), 327-379.

${ }^{58}$ E.g. Bodin (1593), IV.2, 544; V.1, 667, 671, 672, 673, 688.

${ }^{59}$ E.g. Bodin (1593), III.3, 393; VI.6, 1020.

${ }^{60}$ E.g. Bodin (1593), I.9, 162, 204; I.10, 215; III.1, 355, 359; IV.6, 618; V.4, 748 (on Alexander the Great).

${ }^{61}$ E.g. Bodin (1593), I.1, 7; V.6, 794, 799, 800; VI.6, 1051.

${ }^{62}$ Springborg (1992), 197. See Bodin (1593), IV.6, 631; V.4, 748 (“"grandeur \& liberalité”); VI.2, 906.

${ }^{63}$ Bodin (1593), V.1, 672. Also cf. Bodin (1593), V.5, 780.
} 
Florentine's enthusiasm for demographic growth ("there is no wealth nor strength but in men", he famously argued in his Six Books), ${ }^{64}$ while at the same time voicing similar concerns about the delicate balance between territory and population. ${ }^{65}$ On the other hand, he provided the first substantial critique of indiscriminate territorial expansionism, carefully distinguishing between states that must expand, states that can expand, and states that should not or cannot expand. The difference lies not only in the constitutional form of each state (monarchies, for instance, are well suited for expansion, whereas aristocracies are not), ${ }^{66}$ but also in the "natural character of the people" (naturel du peuple) who inhabit it: while Northerners and mountain-dwellers are naturally drawn to warfare on account of the harsh, toughening climate, those who have been favoured with a bountiful environment make very poor soldiers. ${ }^{67}$ Yet excelling at combat is not all that it takes to build an empire: other qualities are needed to maintain what has been acquired, and for this reason the best suited for long-term expansion are not the valiant Northern peoples, but those of the middle region (the so-called temperate zone), who stand out for their political wisdom. ${ }^{68}$

Bodin's point - possibly inspired by Aristotle ${ }^{69}$ - is that a universally valid recipe for success does not exist. Each state must be ruled according to specific conditions - its constitutional regime, the character of its inhabitants - and what works for one country could prove catastrophic for another. Yet, while this is true, the functioning of a state is essentially the same in all cases. Indeed, Bodin's treatise was ground-breaking for its systematic attention to structural elements of statecraft such as public welfare, monetary and fiscal policies, trade, and the regulation of human movements across borders. Although Botero's dependence on Bodin's economic ideas might occasionally have been overblown, ${ }^{70}$ there is little doubt that the Frenchman's novel emphasis on the interconnections between economy and politics, as well as between politics and geography, ${ }^{71}$ was an important source of inspiration for the author of the Greatness of Cities. So was it for so many writers of the following generations, who could read the Six Books of the Commonwealth in any of the numerous editions and translations which appeared from the late sixteenth century onwards. Just as Botero inevitably read Machiavelli through the lens of Bodin, and vice versa, so many readers of

\footnotetext{
${ }^{64}$ Bodin (1593), V.2, 705-706: "Il n'y a de richesse, ny de force, que d'hommes".

${ }^{65}$ Bodin (1593), I.1, 6.

${ }^{66}$ Bodin (1593), V.5, 763-767.

${ }^{67}$ Bodin (1593), V.5, 763 and V.1, 671-674. Cf. Glacken (1976), 435-447.

${ }^{68}$ Bodin (1593), V.5, 671.

${ }^{69}$ Cf. Aristotle, Politics, VII.7 (1327b19-35).

${ }^{70}$ See Descendre (2009), 194-5, for a critical assessment.

71 Botero famously devotes an entire chapter of Reason of State (II.5) to a discussion of environmental influences that owes much to Bodin. See Chabod (1967), 340.
} 
Bodin interpreted his works through those of Botero (again, the reverse is also true). The joint reception of these three authors in the seventeenth century is an extremely complex and fascinating topic which has not yet received the attention it warrants. In the next section, I shall limit myself to a few remarks on the role played by their works in stimulating the English debate on political greatness. ${ }^{72}$

\section{Conflicting Ideals: Bacon, Burton, and the Anatomy of England}

The first decades of the seventeenth century saw the rise of England's maritime power, the intensification of its colonial attempts in Ireland and America, as well as the de facto "regnal union" of England and Scotland under James I (1603-1625). It was a time of exciting change and growth, ${ }^{73}$ but also one of shifting self-representations, conflicting agendas, and lively debates about the direction that the country should take. With Spain and the Netherlands as powerful competitors, England's strive for international predominance could only be successful by candidly assessing the country's strengths and weaknesses, and then by acting to maximise the former and minimise the latter. Such a task became even more pressing in the final years of James I's reign, when the country was threatened by economic instability, scarcity of money and commercial decline, partly in connection with the outbreak of the Thirty Years' War. ${ }^{74}$ It was precisely in those years that two of the most renowned intellectuals of the time, the multitalented Francis Bacon (1561-1626) and the Oxonian scholar Robert Burton (1577-1640), advanced fundamental and largely opposing views on "the true Greatness of Kingdomes and Estates, and the Meanes thereof" 75 - both by engaging with the works of Machiavelli, Bodin and Botero.

Bacon's essay Of the true Greatness of Kingdomes and Estates, composed around 1622 but only published three years later, was in fact the culmination of almost two decades of meditation on this theme. ${ }^{76}$ A shorter version of the same piece had appeared in the 1612 edition of Essays; even earlier, in 1608, Bacon had taken a firm stance on the issue in an unfinished letter to king James I, where he claimed that "true greatness" should not be identified with "largeness of territory", "treasure or riches", "fruitfulness of the soil or

\footnotetext{
72 On reception of Machiavelli in England see Raab (1965); Pocock (2003); Arienzo and Petrina (2013). On reception of Bodin see Burgess (2013); Miglietti (2013). On reception of Botero see Fitzmaurice (2007).

${ }^{73}$ Bowden (1990), 60-61.

${ }^{74}$ See Gould (1955).

${ }^{75}$ Bacon (1985), XXIX, 90.

${ }^{76}$ The composition of the essay can be placed around this date on the basis of internal evidence, namely Bacon's reference to a "Pragmaticall Sanction, now published" which was issued by Philip IV of Spain in 1622: cf. Bacon (1985), XXIX, 95, and Spedding in Bacon (1900a), 127.
} 
affluence of commodities", nor finally with "the strength and fortifications of towns or holds"; instead, "true greatness consisteth essentially in population and breed of men", and specifically in their "valour and military disposition". ${ }^{77}$ Asserting the "predominancy of valour above treasure”, Bacon quoted Machiavelli's famous line that men, not money, are the true "sinews of war"78 - a statement that he had already recalled in an earlier speech to the House of Commons to explain why the "communication of naturalisation" to "the whole Scotch nation" would lead to England's "greatness and power": by incorporating a nation known for its brave and warlike character, he argued, "this kingdom of England" would quickly become "one of the greatest monarchies, in forces truly esteemed, that hath been in the world". ${ }^{79}$

England, besides, was already blessed with a number of natural advantages: the "fit situation of the region", ${ }^{80}$ with "no intermixture or interposition of any foreign land, but only of the sea", of which the English nation was "absolutely master"; ${ }^{81}$ a geographically compact, yet extremely varied territory, each of whose provinces performed different but equally "profitable" functions; ${ }^{82}$ and, most importantly, the "prowess and valour" of the English people, not yet made "slothful and effeminate" nor "insolent and arrogant" by "excess of riches". ${ }^{83}$ Despite this final point, Bacon was not blind to the strategic advantages of wealth. He appreciated that affluent nations are able "to aid and defray great charges for wars" more promptly and for a longer time than poor ones $;{ }^{84}$ he also thought that they are less exposed to a dangerous type of domestic seditions - the "Rebellions of the Belly", as he tellingly called them - which have their first cause in "Want and Necessity". ${ }^{85}$ In his revised version of the essay Of Seditions and Troubles, published in 1625, ${ }^{86}$ Bacon suggested a series of measures intended to prevent popular revolts by promoting economic growth, full employment, and a

\footnotetext{
${ }^{77}$ Bacon (1900c), 233. The letter was published posthumously in 1634.

${ }^{78}$ Bacon (1900c), 243-244, explicitly referencing Machiavelli (1999), II.10, 317; Machiavelli (1965), II.10, 350. Cf. Bacon (1985), XXIX, 91: "The Principal Point of Greatnesse in any State is to have a Race of Military Men. Neither is Money the Sinewes of Warre, (as it is trivially said) where the Sinewes of Mens Armes, in Base and Effeminate People, are failing".

${ }^{79}$ Speech to the House of Commons of 17th February 1606/1607, quot. by Spedding in Bacon (1900c), 221-222. In "The true greatness of Britain" Bacon similarly argues that the granting of the rights of citizenship to the Latins and the Gauls was what allowed Rome to "grow great": Bacon (1900c), 238. Also cf. Bacon (1900b), 378 ("States liberall of naturalization, are capable of greatnesse"); Bacon (1985), XXIX, 93-94.

${ }^{80}$ Bacon (1900c), 252.

${ }^{81}$ Bacon (1900c), 242.

82 Bacon (1900c), 240-241.

${ }^{83}$ Bacon (1900c), 248.

${ }^{84}$ Bacon (1900c), 250.

${ }^{85}$ Bacon (1985), XV, 45.

${ }^{86}$ An earlier version of this essay was published in the second edition of 1612 , but most of the passages quoted here were introduced in the revised version of 1625 .
} 
positive balance of trade. ${ }^{87}$ As he was keen to stress, however, wealth was only beneficial if it made the whole country rich, and not just a small portion of it; if it was used for the profit of all, rather than selfishly squandered by a minority. Wealth should be "dispersed" among the active classes - "merchants, burghers, tradesmen, freeholders, farmers", 88 who "live lower, and gather more" 89 - rather than "ingrossed" in the wasteful "hands of the nobility and gentlemen", ${ }^{90}$ who "spend more, and earne less". ${ }^{91}$ Then, and only then, would wealth "add true greatness and strength to a state". ${ }^{92}$

Bacon was convinced that the displacement of social and economic power from the unproductive classes to the labourers would also exert positive effects on the "Breed and disposition of the people": 93 "Let States that aime at Greatnesse, take heed how their Nobility and Gentlemen doe multiply too fast," he wrote in 1625, rephrasing a concept already expressed in 1612, "for that maketh the Common Subject grow to be a Peasant, and Base Swaine, driven out of Heart". ${ }^{94}$ Speaking out against the advocates of indiscriminate population growth, Bacon argued that it was pointless, not to say dangerous, for a state to have "Great Population and Little Strength": 95 an overpopulated country full of hungry and degraded subjects makes a poor candidate for "Empire and Greatnesse" 96 and an ideal cradle for civic discord. Such a proportion must therefore be kept between "the Population of a Kingdome" and "the stock of the Kingdome which should maintain them", "as may breed a Subject to live in Convenient Plenty, and no Servile Condition", 97

Bacon's emphasis on human qualities rather than numbers, ${ }^{98}$ as well as his continuous insistence on the "essential difference between the scale of miles and the scale of forces", ${ }^{99}$ have induced some scholars to speculate that the English philosopher might have developed his ideas on greatness in opposition to Botero. ${ }^{100}$ As shown above, however, Botero too allowed that sheer quantity (of territory, riches, population) was only a feeble indicator of a state's "greatness". Like Bacon, he agreed with Machiavelli that valour, not money, was the

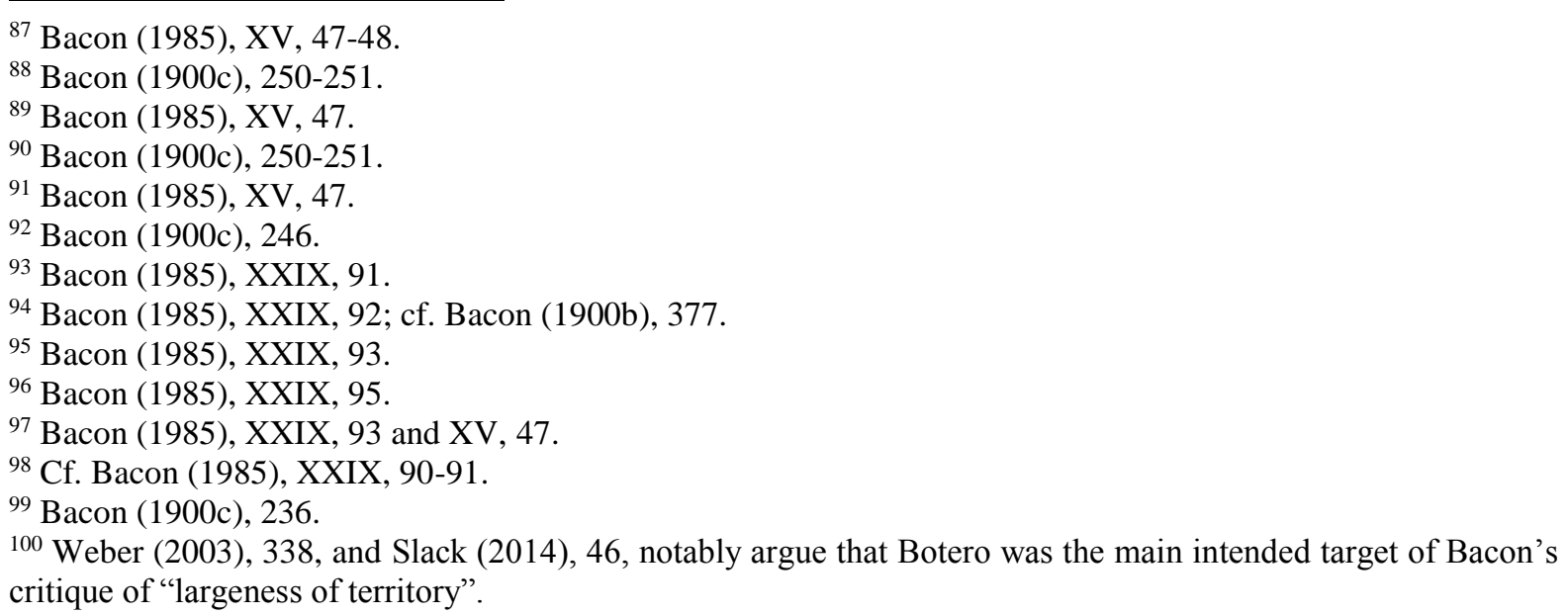


true "sinews of war" (nervo della guerra), and quoted Bodin's famous motto that "there is no wealth nor strength but in men". ${ }^{101}$ Far from being an uncritical advocate of territorial expansion, he was alert to what Bacon called the "weakness of states possessed of large territories", ${ }^{102}$ and recommended a more intensive exploitation of existing resources and the improvement of living conditions for all as key components of genuine political development. As readers of Machiavelli and Bodin, ${ }^{103}$ Bacon and Botero also shared a common vision of the Romans as a clever empire-building nation who adopted policies such as the "communication of naturalisation" and the foundation of settler colonies to increase their population and thus their "forces". ${ }^{104}$

At the same time, Bacon was less rigidly opposed to territorial expansion than is often thought. It suffices to look at his Latin self-translation of The true Greatness of Kingdomes and Estates, which appeared in the eight book of De augmentis scientiarum (1623), to realise that Bacon's "greatness" (indifferently translated with magnitudo and amplitudo) had a lot to do with "pushing the state's borders farther", as is literally stated in the Latin title of the essay ("De proferendis finibus imperii"): indeed, "augmenting the state and extending its borders" was described here as a task of equal importance as "preserving the state" and "making it happy and prosperous". ${ }^{105}$ Such emphasis on territorial expansion was not necessarily in contradiction with the mistrust for large empires so vocally expressed in Bacon's 1608 letter to James I. While claiming that "largeness of territory is so far from being a thing inseparable from greatness of power, as it is many times contrariant and incompatible with the same", Bacon had also specified a series of conditions under which "greatness of territory" does in fact "add strength". ${ }^{106}$ First and foremost among such conditions was that "the territories be compacted, and not dispersed": ${ }^{107}$ while the "defence" of "provinces dispersed [...] doth commonly consume and decay and sometimes ruin the rest of the estate", ${ }^{108}$ it is much easier to keep a hold on colonies and dominions that are within close and easy reach from the mother-country. ${ }^{109}$ Here again Bacon was following Botero, who had similarly drawn attention to distance as a discriminating factor in choosing the seat for a colony, and preferred

\footnotetext{
${ }^{101}$ Botero (1956b), VII.10, 141 and (1990b), VII, 197.

102 Bacon (1900c), 234.

${ }^{103}$ A full study of Bacon's relationship with Bodin has not yet been done; but cf. Yates (1999), 145.

${ }^{104}$ See Bacon (1985), XXIX, 94.

105 Bacon (1900a), 120 (my translation).

${ }^{106}$ Bacon (1900c), 236-237.

${ }^{107}$ Bacon (1900c), 237.

${ }^{108}$ Bacon (1900c), 238.

${ }^{109}$ Bacon (1900c), 237-238.
} 
the Roman way of "sending colonies near the mother-country" over the frail transatlantic empire of the Spanish and the Portuguese. ${ }^{110}$

Where Botero and Bacon crucially disagreed was in assessing England's "forces" and its chances of future greatness. In this regard, Bacon's 1608 letter to James I may be read as a sort of counterpoint to Botero's preamble to the second book of Universal Relations, which only a few years before (1601) had been translated into English. ${ }^{111}$ In this section, dedicated to the question of how to "extend one's empire" (estendere il dominio), Botero carefully discussed all the factors that would later reappear in Bacon's letter on greatness: abundance of people, military valour, money and wealth, nature of the site and so forth. Among the countries favoured with an advantageous location Botero mentioned England, whose vast plains surrounded on all sides by the sea were open to all sorts of commercial exchanges yet easy to protect from the enemy. "How come then," he asked, "that islands endowed with such a site have never had a great empire (dominio grande)?" His answer was that just as "land forces are superior to maritime forces", so maritime empires, however powerful, are always weaker than land empires: "no empire can be great unless it extends itself inland". ${ }^{112}$ Bacon's reaction was prompt: "To be Master of the Sea, is an Abridgement of a Monarchy," he wrote in $1622,{ }^{113}$ adding that "hee that Commands the Sea, is at great liberty, and may take as much, and as little of the Warre, as he will. Whereas those, that be strongest by land, are many times nevertheless in great Straights". ${ }^{114}$ Consequently, Bacon's picture of England's future greatness, framed in opposition to Botero's preamble, envisaged a relatively small land empire (limited to the British Isles) with a firm hold on key commercial bases in Europe and maritime trade routes across the globe. ${ }^{115}$

\footnotetext{
${ }^{110}$ Botero (1956b), VIII.5, 157 and (1990b), VIII, 219. Yet Botero was better disposed in principle towards "dispersed states" (stati disuniti), especially if all of their provinces could easily be defended by sea: cf. Botero (1956b), I.7, 11 and (1990b), I, 13, referring again (this time approvingly) to Spain and Portugal.

111 This was the second, expanded edition of Robert Johnson's translation (printed in London by John Jaggard as The worlde, or an historicall description of the most famous kingdomes and common-weales). An earlier edition, also published by Jaggard in 1601 but entitled The Travellers Breviat, did not contain the preamble to book 2. See Shackleton (1948), 405-406.

112 Botero (1596), II, "Proemio" (unpaged).

${ }^{113}$ Bacon (1985), XXIX, 97. Cf. Bacon (1900a), 132: "Maris Dominium monarchiae quaedam epitome est". Cf. Bacon (1900c), 233: "true greatness[...] consisteth in the commandment of the sea".

114 Bacon (1985), XXIX, 98. In fact, Botero too conceded that maritime forces, while they might not add "strength" (nervo), do usefully contribute "greater mobility" (agilità), making it possible to "attack the enemy unexpectedly in many places and to keep him continually undecided": Botero (1956b), X.7, 217-218 and (1990b), X, 301.

${ }^{115}$ In his speech at the House of Commons of 17th February 1606/1607, Bacon dreamed of having "Scotland united, Ireland reduced, the sea provinces of the Low Countries contracted, and shipping maintained": quot. by Spedding in Bacon (1900c), 222.
} 
Other readers of Botero, however, came to different conclusions. As noted by Fitzmaurice, Botero's theory of greatness "attracted many adherents who were at the forefront of colonization". 116 For men such as Robert Johnson and Walter Raleigh, both personally involved in England's colonial efforts in North America, ${ }^{117}$ Botero's ideas on empire were an important source of guidance. Raleigh, whose Observations concerning the Causes of the Magnificency and Opulence of cities (probably composed in the early seventeenth century, but published posthumously in 1651) are actually an abridged translation of Botero's Greatness of Cities ${ }^{118}$ was “one of the first to see in Botero's writing a means of emulating and therefore rivaling Spanish grandezza"119 - quite ironically, in fact, given "Botero's proSpanish sentiments". ${ }^{120}$ Competition with Spain was also Johnson's primary motivation for producing no less than six English translations of Botero's Universal Relations, whose textual layers - closely examined in a recent study by Paul and Meshkat - reveal Johnson's "attempts to intervene in British international policy-making by putting forward a specific vision of global order as maintained by a British empire balancing that of the Spanish". ${ }^{21}$ Behind such efforts was a reading of Botero that took seriously the latter's calls for inland expansion, the establishment of colonial settlements, and - in Raleigh's case - urban growth as vital measures towards a strong empire.

Despite their disagreements, Bacon, Johnson and Raleigh all shared a relatively optimistic view of England as a world power with legitimate aspirations to greatness; the Oxonian scholar Robert Burton, on the other hand, saw things from a radically different perspective. The first edition of his monumental masterpiece, The Anatomy of Melancholy, came out in 1621 , only a few months into the economic crisis that shattered the final years of James I; Burton, who already had a clear sense of its gravity, ${ }^{122}$ devoted large part of his general preface to analysing its causes in detail, in close intertextual dialogue with Botero's

\footnotetext{
${ }^{116}$ Fitzmaurice (2007), 798.

117 Johnson (dates unknown) was deeply involved with the Virginia Company and in 1609 published a promotional text entitled Nova Britannia, Offering Most Excellent Fruites by Planting in Virginia (see Fitzmaurice, 2007; Paul and Meschkat, 2013). Raleigh (ca. 1554-1618) took personally part in the exploration and colonisation of Virginia, where he founded the unsuccessful colony of Roanoke Island.

118 See Symcox in Botero (2012), xiv.

${ }^{119}$ Fitzmaurice (2007), 798.

${ }^{120}$ Paul and Meshkat (2013), 127.

${ }^{121}$ Paul and Meshkat (2013), 110. Johnson's translations came out in 1601 (two editions), 1603, 1608, 1611, and 1616. A new translation expanding on the 1616 edition came out in 1630, but it was no longer the work of Johnson.

${ }^{122}$ See De Oliveira (2003).
} 
writings, ${ }^{123}$ as well as with those of Machiavelli, Bodin and others. "Our land is fertile wee may not deny, full of good thinges, and why doth it not then abound with Citties, as well as Italy, France, Germany, the Low countries?" he wondered in his preface. ${ }^{124}$ The search for an answer led him to paint a dreadful image of England as a country overwhelmed by melancholy, ${ }^{125}$ "a Paradise turned to a wilderness": 126

so many thousand acres of our fens lye drowned, our Cities thin, and those vile, poore, and ugly to behold [...] our trades decayed, our still running rivers stopped, and that beneficiall use of transportation, wholly neglected, so many Havens void of ships and Townes, so many Parkes and Forrests for pleasure, barren Heaths, so many villages depopulated. ${ }^{127}$

While the Low-Countries are described as an "epitome of China by reason of their industry and commerce", ${ }^{128}$ England stands as a painful example of self-inflicted decadence. For Burton, the chief causes of the country's decline were indeed bad government ${ }^{129}$ and the natural laziness of the English people: "Idlenesse is the MALUS GENIUS of our Nation. For as Boterus justly agrees, fertility of a Country is not enough, except Art and Industry be joined unto it". ${ }^{130}$ Industry is what makes "a barren soyle to be fertile and good": it is "a load-stone to draw all good things", ${ }^{131}$ the one infallible means "to the ornament and enriching of a kingdom". ${ }^{132}$ Without industry, the richest country decays; where industry thrives, on the other hand, "you shall see the people civill [...] peaceable and quiet, rich, fortunate, and flourish, to live in peace, in unity and concord, a Country well tilled, many faire built and populous Citties". 133

While they both drew on Botero's writings to develop their theories, Burton's view of England was in many respects at odds with that of Bacon. Idleness, which the former saw as the root of all ills, was for Bacon a distinctive trait of "all Warlike People", thus a quality to

\footnotetext{
123 See Gowland (2006), 234. Burton quotes from Draud's Latin translation of Reason of State and The Greatness of Cities, published in 1602 (Ursellis: Apud Cornelium Sutorium, impensis Lazari Zetzneri) as Tractatus duo: De Illustrium statu \& politia libris X; De origine urbium... libris III).

${ }^{124}$ Burton (1989), 76. Since this edition is based on the 1635 print, I have collated its text with that of the first edition of 1621 to ascertain the absence of variants in the passages quoted here.

${ }^{125}$ Burton (1989), 66-67. Cf. De Oliveira (2003).

${ }^{126}$ Burton (1989), 74.

${ }^{127}$ Burton (1989), 75.

${ }^{128}$ Burton (1989), 77.

${ }^{129}$ Burton (1989), 74 and 76.

${ }^{130}$ Burton (1989), 76. The reference is to Botero (1956a), I.9, 235 and (1990a), I, 320.

${ }^{131}$ Burton (1989), 77.

${ }^{132}$ Burton (1989), 78,

${ }^{133}$ Burton (1989), 66.
} 
encourage, rather than curb, "if they shall be preserved in vigour". ${ }^{134}$ Clearly Burton did not share Bacon's dreams of "Martiall Greatnesse"; his plan for the regeneration of England focused on intensive development of the country's lands rather than on struggles for territorial expansion. "The lesser the Territory is, commonly the richer it is", he wrote in fact, offering a number of examples from Botero's writings. ${ }^{135}$ Not by chance, that "UTOPIA of mine own, a new ATLANTIS", ${ }^{136}$ which he sketched in the final pages of the preface, was an exemplary experiment in land management that would inspire generations of British thinkers and "improvers" after him. ${ }^{137}$

\section{Conclusions}

All concepts have a history, and the hundred years that separate Machiavelli's Discourses from the final edition of Bacon's Essays were arguably a golden age in the century-long history of "greatness". For Fitzmaurice, grandezza is the essential concept in the history of early modern state- and empire-building, as its pursuit "facilitated the transformation of Europe's numerous feudal political units, cities, and principalities into the beginnings of the modern state system"; for Pocock, the long shadow cast by Machiavelli's grandezza marked the entire politico-intellectual life of the seventeenth century. ${ }^{138}$ What has not been sufficiently emphasised thus far, however, is that in the course of these hundred years Machiavelli's grandezza changed shape and took on new meanings as it was translated into different languages, applied to new contexts and adapted to the political agendas that it helped create.

This chapter has sought to show how the debate over the meaning of "greatness" and the proper ways to achieve it brought together thinkers from the four corners of Europe to engage in a lively intertextual conversation which was not without consequences at the level of actual policy-making. Machiavelli, Bodin and Botero quickly came to represent a canon of authors to whom any discussion of "greatness" should necessarily refer. In England, where the reception of their works was particularly intense, opposing understandings of what "true greatness" is stimulated writers such as Bacon, Johnson, Raleigh and Burton to develop different schemes for the advancement (or the regeneration) of the country.

\footnotetext{
${ }^{134}$ Bacon (1985), XXIX, 95.

${ }^{135}$ Burton (1989), 78. The reference is in particular to Botero (1956b), VIII.3, 150-153 and (1990b), VIII, 210214.

${ }^{136}$ Burton (1989), 85.

${ }^{137}$ Cf. Burton (1989), 88-89; on improvement see Slack (2014).

${ }^{138}$ Pocock (2003), part 3.
} 
But the history of "greatness" does not end here: the concept was still to have a fascinating afterlife, for instance in France - Rousseau's chapter on "The People" in the second book of Social Contract is in part a meditation on what a state's "true greatness" (véritable grandeur) is, and how it can be measured and achieved ${ }^{139}$ - and Scotland, if Istvan Hont is right in suggesting that "the positive core of Machiavellian ideas of grandezza, namely that flourishing political communities had to be able to grow" inspired Adam Smith's thesis that "the most flourishing political communities were not the richest, but the ones that grew the fastest". ${ }^{140}$ While a complete genealogy of "greatness" will have to wait for future studies, following its trajectories from the first decades of the Cinquecento to the early seventeenth century has enabled us to shed some light on an exemplary case of unceasing dialogue between the Renaissance and the early modern period.

\section{Bibliography}

\section{Primary sources}

Bacon, Francis. 1900a. De proferendis finibus imperii (De augmentis scientiarum, VIII.3). In The Works of Francis Bacon, ed. James Spedding et al., vol. 3, 120-135. Boston: Houghton, Mifflin and Company.

Bacon, Francis. 1900b. Of the Greatnesse of Kingdomes. In The Works of Francis Bacon, ed. James Spedding et al., vol. 12, 376-378. Boston: Houghton, Mifflin and Company.

Bacon, Francis. 1900c. On the true greatness of Britain. In The Works of Francis Bacon, ed. James Spedding et al., vol. 13, 219-255. Boston: Houghton, Mifflin and Company.

Bacon, Francis. 1985. The Essayes or Counsels, Civill and Morall, ed. Michael Kiernan. Oxford: Clarendon Press.

Bodin, Jean. 1593. Les Six Livres de la Republique. Lyon: Barthelemy Vincent.

Botero, Giovanni. 1990a. Cause della grandezza e magnificenza delle città. In Della ragion di Stato, $e$ Cause della grandezza e magnificenza delle città, ed. Luigi Firpo. Bologna: Forni. English translations: Botero, Giovanni. 1956a. The Greatness of Citties. In The Reason of State \& The Greatness of Cities (trans. Robert Peterson), ed. D.P. Waley. London: Routledge and Kegan Paul. Botero, Giovanni. 2012. On the Causes of the Greatness and Magnificence of Cities (trans. Geoffrey Symcox). Toronto: University of Toronto Press.

Botero, Giovanni. 1990b. Della ragion di Stato. In Della ragion di Stato, e Cause della grandezza e magnificenza delle città, ed. Luigi Firpo. Bologna: Forni. English translation: Botero, Giovanni. 1956b. The Reason of State. In The Reason of State \& the Greatness of Cities (trans. P.J. and D.P. Waley), ed. D.P. Waley. London: Routledge and Kegan Paul.

Burton, Robert. 1989. The Anatomy of Melancholy. Volume I, ed. Thomas C. Faulkner et al. Oxford: Clarendon Press.

Machiavelli, Niccolò. 1999. Discorsi sopra la prima deca di Tito Livio (ed. Giorgio Inglese). Milano: BUR. Latin translation: Machiavelli, Niccolò. 1588. Disputationum de republica libri (trans. Johann Nikolaus Stupanus). Mompelgarti (Montbéliard): Per Iacobum Folietum Typographum. English translation: Machiavelli, Niccolò. 1965. Discourses on the First Decade of Titus Livius. In The Chief Works and Others (trans. Allan Gilbert), vol. 1. Durham, NC: Duke University Press.

\footnotetext{
${ }^{139}$ Rousseau (1992), II.10, 73-74; cf. Rousseau (1997), 75-77.

${ }^{140}$ Hont (2008), 307.
} 
Rousseau, Jean-Jacques. 1992. Du contrat social, ed. Pierre Burgelin. Paris: Garnier Flammarion English translation: Rousseau, Jean-Jacques. 1997. The Social Contract and Other Later Political Writings (trans. Victor Gourevitch). Cambridge: Cambridge University Press.

\section{Secondary sources}

Arienzo, Alessandro, and Alessandra Petrina (eds). (2013). Machiavellian Encounters in Tudor and Stuart England. Literary and Political Influences from the Reformation to the Restoration. Aldershot: Ashgate

Armitage, David. 2002. Empire and Liberty: A Republican Dilemma. In Republicanism: a Shared European Heritage, ed. Martin van Gelderen and Quentin Skinner, vol. 2, 29-46. Cambridge: Cambridge University Press.

Bowden, Peter J. 1990. Agricultural Prices, Farm Profits and Rents 1500-1640. In Id. Economic Change: Wages, Profits and Rents, 1500-1750. Chapters from The Agrarian History of England and Wales, volume 1, Cambridge: Cambridge University Press.

Brown, Alison. 2004. The Language of Empire. In Florentine Tuscany. Structures and Practices of Power, ed. William J. Connell and Andrea Zorzi, 32-47. Cambridge: Cambridge University Press.

Burgess, Glenn. 2013. Bodin in the English Revolution. In The Reception of Bodin, ed. Howell A. Lloyd, 387-407. Leiden: Brill.

Chabod, Federico. 1967. Giovanni Botero. In Id. Scritti sul Rinascimento. Torino: Einaudi.

Descendre, Romain. 2009. L'état du monde. Giovanni Botero entre raison d'État et géopolitique. Genève: Droz.

Elliott, J.H. 1977. Self-Perception and Decline in Early Seventeenth-Century Spain. Past and Present 74/1:41-61.

Fitzmaurice, Andrew. 2007. The Commercial Ideology of Colonization in Jacobean England: Robert Johnson, Giovanni Botero, and the Pursuit of Greatness. The William and Mary Quarterly 64/4:791820.

Glacken, Clarence. 1976. Traces on the Rhodian Shore. Nature and Culture in Western Thought from Ancient Times to the End of the Eighteenth Century. Berkeley: University of California Press.

Gould, J.D. 1955. The Trade Crisis of the Early 1620s and English Economic Thought. Journal of Economic History 15:121-33.

Gowland, Angus (2006). The Worlds of Renaissance Melancholy: Robert Burton in Context. Cambridge: Cambridge University Press.

Hankins, James. 1995. The "Baron Thesis" after Forty Years and some Recent Studies of Leonardo Bruni. Journal of the History of Ideas 56:309-338.

Hankins, James. 2000. Rhetoric, History, and Ideology: The Civic Panegyrics of Leonardo Bruni. In Renaissance Civic Humanism Reconsidered, ed. James Hankins, 143-78. Cambridge: Cambridge University Press.

Hartman, Jan, and Arthur Weststeijn. 2013. An Empire of Trade. In The Political Economy of Empire in the Early Modern World, ed. Sophus Reinert and Pernille Røge, 11-31. Basingstoke-New York: Palgrave Macmillan.

Hont, Istvan. 2008. The "Rich Country- Poor Country" Debate in Scottish Classical Political Economy. In David Hume's Political Economy, ed. Carl Wennerlind and Margaret Schabas, 243-323. Oxford-New York: Routledge.

Hörnqvist, Mikael. 2004. Machiavelli and Empire. Cambridge: Cambridge University Press.

Miglietti, Sara. 2013. Reading from the Margins: Some Insights into the Reception of Bodin's Methodus in England. In The Reception of Bodin, ed. Howell A. Lloyd, 193-217. Leiden: Brill.

Najemy, John. 2000. Civic Humanism and Florentine Politics. In Renaissance Civic Humanism Reconsidered, ed. James Hankins, 75-104. Cambridge: Cambridge University Press.

Paul, Joanne, and Kurosh Meschkat. 2013. Johnson's Relations: Visions of Global Order, 1601-1630.

The Journal of Intellectual History and Political Thought 2/1:108-140. 
Pocock, John. 2003. The Machiavellian Moment: Florentine Political Thought and the Atlantic Republican Tradition. Princeton, NJ: Princeton University Press.

Raab, Felix. 1965. The English Face of Machiavelli: A Changing Interpretation, 1500-1700. London: Routledge and Kegan Paul.

Reinert, Sophus A. 2011. Translating Empire. Emulation and the Origins of Political Economy. Cambridge, Mass.: Harvard University Press.

Ruffo Fiore, Silvia. 1990. Niccolò Machiavelli: An Annotated Bibliography of Modern Criticism and Scholarship. Portsmouth, NH: Greenwood Publishing Group.

Shackleton, Robert. 1948. Botero, Bodin and Robert Johnson. The Modern Language Review 43/3:405-409.

Skinner, Quentin. 1995. The State. In Political Innovation and Conceptual Change, ed. Terence Ball et al., 90-131. Cambridge: Cambridge University Press.

Skinner, Quentin. 2003. The Vocabulary of Renaissance Republicanism: A Cultural longue durée? In Language and Images of Renaissance Italy, ed. Alison Brown, 87-110. Oxford: Clarendon Press.

Slack, Paul. 2014. The Invention of Improvement. Information and Material Progress in SeventeenthCentury England. Oxford: Oxford University Press.

Springborg, Patricia. 1992. Western Republicanism and the Oriental Prince. Cambridge: Polity Press Stangeland, Charles Emil. 1904. Pre-Malthusian Doctrines of Population: A Study in the History of Economic Theory. New York: Columbia University Press.

Yates, Frances. 1999. The Mystery of Jean Bodin. In Ideas and Ideals in the North European Renaissance: Collected Essays, 139-152. London-New York: Routledge and Kegan Paul. 